\title{
Successful medical drainage and surgical treatment for vertebral osteomyelitis and bilateral psoas abscess with gas formation caused by klebsiella pneumoniae in a diabetic patient
}

\author{
Wei-Yang $Y u^{1}$ \\ (iD) Ke-Jun Zhu ${ }^{1}$ \\ (iD) Qiao-Ping Li ${ }^{1}$ \\ (iD) Chao Lou' \\ (iD) Deng-Wei He ${ }^{1}$
}

1. Department of Orthopaedic Surgery, Zhejiang University, Lishui Municipal Central Hospital, Lishui, Zhejiang, 323000, P.R. China

http://dx.doi.org/10.1590/1806-9282.65.5.678

\section{SUMMARY}

OBJECTIVE: We describe the case of a diabetic patient who developed vertebral osteomyelitis and bilateral psoas abscess with gas formation due to klebsiella pneumoniae.

METHODS: A 64-year-old woman with a 4-year history of type-2 diabetes mellitus was admitted to the Emergency Department. The subject had a 2-day history of high-grade fever associated with chills and a 5-hour history of consciousness. She received empirical treatment with febrifuge, after which her fever decreased.

RESULTS: Her fever recurred after an interval of three hours. A computed tomography scan of the abdomen revealed vertebral osteomyelitis and bilateral psoas muscle abscess with gas formation. Blood culture and purulent fluid described the growth of the Klebsiella pneumoniae. The patient received antibiotic therapy and bilateral drainage therapy after the drainage catheter was placed into the abscess cavity by CT-guidance. Due to the serious damage to the vertebral column and permanent pain, the patient underwent minimally invasive internal spinal fixation and recovered successfully.

CONCLUSION: A case of vertebral osteomyelitis and bilateral psoas abscess with gas formation caused by Klebsiella pneumoniae in a diabetic patient. Antibiotic therapy, drainage, and minimally invasive internal spinal fixation were performed, which enabled a good outcome.

KEYWORDS: Osteomyelitis. Psoas abscess. Klebsiella pneumoniae. Minimally Invasive Surgical Procedures. Diabetes Mellitus.

\section{INTRODUCTION}

Vertebral osteomyelitis and bilateral psoas abscess with gas formation caused by Klebsiella pneumoniae is a rare but life-threatening infection. It may lead to mortality if early diagnosis and effective man- agement are not carried out. It frequently occurs in a variety of serious complications such as pneumonia, septic shock, and multiple organ failure. In this report, we present a case of vertebral osteomyelitis and 
bilateral psoas abscess with gas formation caused by Klebsiella pneumoniae in a 64-year-old woman with poorly controlled diabetes mellitus and review cases previously reported in the literature.

\section{CASE REPORT}

A 64-year-old woman with a 4-year history of type-2 diabetes mellitus was admitted to the Emergency Department. The patient had a 2-day history of high-grade fever associated with chills and a 5-hour history of consciousness. She had no history of coronary disease, obesity, and hypertension and was empirically treated with febrifuge, after which her fever decreased. However, her fever recurred after three hours. Upon physical examination, the patient was acutely ill-looking and had consciousness. Her body temperature was $39.2^{\circ} \mathrm{C}$, pulse rate was $124 /$ $\mathrm{min}$, respiratory rate was $40 / \mathrm{min}$, blood pressure was $116 / 76 \mathrm{mmHg}$, and oxygen saturation was $90 \%$. Ulceration of the skin was noticed on her right heel and in the lumbosacral region.

Hemoglobin (HB) level was $11 \mathrm{~g} / \mathrm{L}$. White blood cell (WBC) count and blood platelet (PLT) count were within the normal limits. The C-reactive protein level was $200 \mathrm{mg} / \mathrm{L}$, and procalcitonin level was $7.86 \mathrm{ng} /$ $\mathrm{ml}$. Also, the fasting plasma glucose level was 50 $\mathrm{mmol} / \mathrm{L}$, arterial blood gas analysis revealed a $\mathrm{pH}$ of 7.434 , the partial pressure of oxygen was $57.9 \mathrm{mmHg}$, and serum concentrations of $\mathrm{Na}+$ ion and $\mathrm{K}+$ ion were $159 \mathrm{mmol} / \mathrm{L}$ and $2.9 \mathrm{mmol} / \mathrm{L}$, respectively. An electrocardiogram revealed nodal tachycardia. Urine analysis, stool analysis, head magnetic resonance imaging (MRI) and abdominal ultrasound did not reveal any clinical finding. Due to persistent fever and increased C-reactive protein level and procalcitonin level, she received empirical anti-infectious treatment. Abdominal CT revealed osteomyelitis at the $\mathrm{L} 2$ vertebral body and bilateral psoas muscle abscess with gas formation (Figure 1). On day three, blood culture yielded Klebsiella pneumoniae. Meropenem and moxifloxacin were used to the patient's targeted therapeutic regimen when Klebsiella pneumoniae was identified. However, on day five, the patient's fever persisted, and inflammatory markers remained high. At this point, intravenous vancomycin was started. On day 9, a drainage catheter was inserted by CT-guidance due to enlargement of the right psoas abscess (Figure 2), yielding $100 \mathrm{ml}$ of purulent fluid. On day 18 , the right drainage tube was taken out. On day 25 , the patient was sent to the operating room and received minimally invasive internal spinal fixation due to the worsening of vertebral destruction at the L2 lev$\mathrm{el}^{1}$ (Figure 3). The operation was successful. On day 33 , due to the enlargement of the left psoas abscess, CT-guided drainage of the left psoas abscess was performed, and purulent material was allowed to flow out. However, cultures of the purulent material were negative. Therapy with ceftazidime was continued, and meropenem and vancomycin were discontinued. On day 40 , the left drainage tube was taken out. On day 46 , laboratory values were as follows: leukocyte count was $7,900 / \mathrm{\mu L}$, and C-reactive protein was $10.38 \mathrm{mg} / \mathrm{L}$. MRI revealed that the position of eight pedicle screws fit well. On day 47 , the patient was discharged. After one year of follow-up after surgery,

FIGURE 1. ABDOMINAL CT SHOWED OSTEOMYELITIS AT L2 VERTEBRAL BODY AND BILATERAL PSOAS MUSCLE ABSCESS WITH GAS FORMATION.

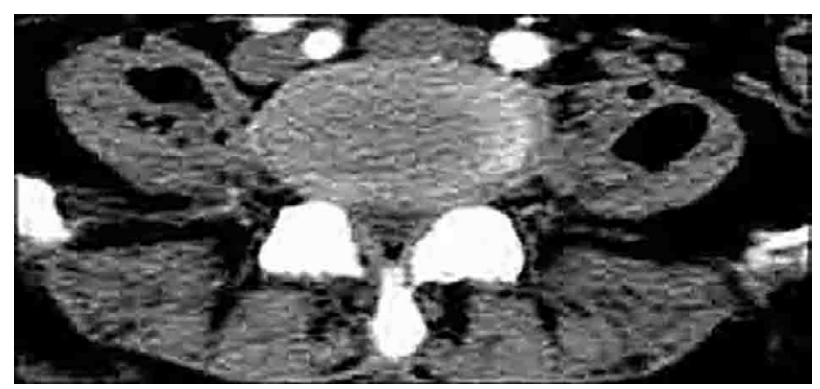

FIGURE 2. A CT-GUIDED DRAINAGE CATHETER WAS INSERTED DUE TO THE ENLARGEMENT OF THE RIGHT PSOAS ABSCESS.

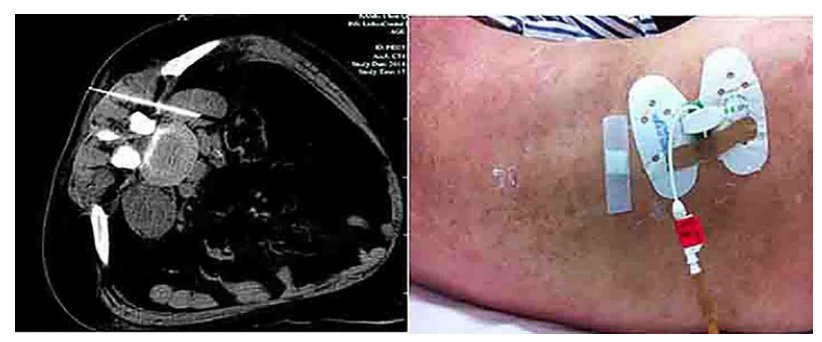

FIGURE 3. MINIMALLY INVASIVE INTERNAL SPINAL FIXATION.

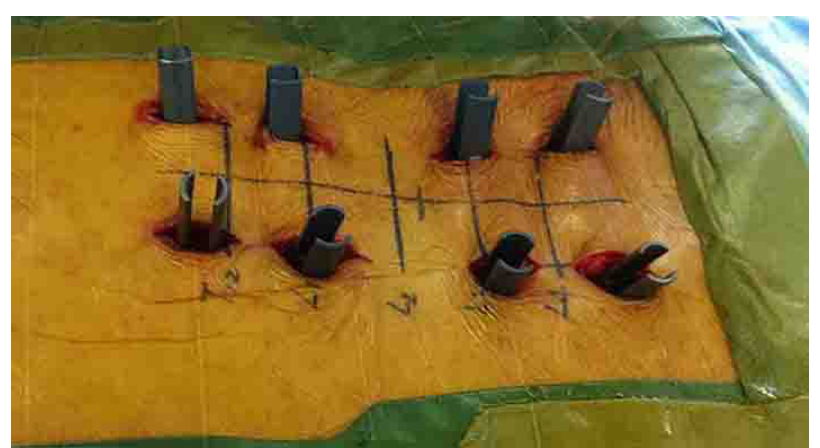


the patient had no evidence of recurrence, and the CT revealed that the bilateral psoas muscle abscess was apparently reduced.

\section{DISCUSSION}

Vertebral osteomyelitis and bilateral psoas abscess with gas formation caused by Klebsiella pneumoniae is a relatively uncommon disease, and its early diagnosis remains a challenging issue. Diabetes mellitus, immunocompromised conditions, and trauma are major risk factors. Chang et al. ${ }^{2}$ has reported seven cases of psoas abscess caused by Klebsiella pneumoniae. Results revealed that early recognition, empiric antimicrobial coverage for Klebsiella pneumoniae, and aggressive drainage are necessary ${ }^{2}$. Klebsiella pneumoniae is a non-spore-forming gram-negative bacillus that is pathogenic for human beings, especially for immunocompromised patients ${ }^{3}$. Klebsiella pneumoniae generally infects the lung by directly spreading through the airway and rarely causes infections of the central nervous system, joint, and bone.

Classical symptoms of psoas muscle abscess involve limping, lower back pain and persistent fever with daily spikes ${ }^{4}$. However, the patient had no localized symptom in our presented case. The reported common causative pathogens of psoas muscle abscess in Ricci et al. ${ }^{5}$ are Staphylococcus aureus (190 cases, 88.4\%), Streptococci (12 cases, 4.9\%), and Escherichia coli (seven cases, 2.8\%). In our case, gram-positive bacillus and anaerobic bacteria were primarily considered as causative pathogens. However, purulent material and blood culture yielded Klebsiella pneumoniae. Ultrasonography is a tool that is readily available but is neither specific nor sensitive. CT is the most sensitive tool for a definitive diagnosis of psoas muscle abscess ${ }^{3}$.

Vertebral osteomyelitis is a potentially life-threatening infection ${ }^{6}$. According the report by McHenry et al. ${ }^{7}$, Staphylococcus aureus, coagulase-negative Staphylococci, Escherichia coli, Streptococci, Proteus mirabilis, Pseudomonas aeruginosa, Salmonella species, and Klebsiella pneumoniae were considered causative pathogens of vertebral osteomyelitis. The diagnoses of vertebral osteomyelitis were based on clinical features, imaging findings, and laboratory examination. Relief of pain, prevention of recurrence, eradication of infection, prevention of neurologic defects and restoration of spinal stability are the general objectives of treatment ${ }^{8}$.

Systemic antimicrobial therapy and surgical drainage are the traditional treatment for psoas muscle abscess ${ }^{9}$. Antimicrobial therapy according to drug susceptibility is essential to prevent the emergence of a drug-resistant strain ${ }^{3}$. In the past, abscess drainage was commonly performed using surgical procedures. With the improvement of computer and imaging techniques, percutaneous drainage has become the primary treatment for psoas abscess through CT or ultrasound-guidance, especially when there is a high risk for surgery ${ }^{10}$. Bilateral percutaneous drainage was performed in our case. Conservatively, patients with vertebral osteomyelitis can be treated with intravenous antibiotics. However, surgical treatment is considered when the conservative treatment is unsuccessful. The surgical strategy for vertebral osteomyelitis is currently continuously evolving ${ }^{8}$. Spinal internal fixation is one of the currently used methods for the surgical treatment of vertebral osteomyelitis. In our case, antimicrobial therapy treatment in patients was unsuccessful. Therefore, minimally invasive internal spinal fixation was performed for the treatment of vertebral osteomyelitis due to severe damage to the vertebral column.

In summary, we report a case of vertebral osteomyelitis and bilateral psoas abscess with gas formation caused by Klebsiella pneumoniae in a diabetic patient. Antibiotic therapy, drainage, and minimally invasive spinal internal fixation were performed, which enabled a good outcome in our case. Klebsiella pneumoniae should be considered a critical pathogen that causes vertebral osteomyelitis and bilateral psoas abscess with gas formation in diabetics. Early and accurate diagnosis should be made to prevent the exacerbation of this disease. Long-term follow-ups are needed to determine its potential for recurrence.

Funding: Medical and Health and Technology Project of Zhejiang Province (2018KY937). 


\section{RESUMO}

OBJETIVO: Descrever o caso de uma paciente diabética que desenvolveu osteomielite vertebral e abcesso bilateral do psoas com formação de gás causada por klebsiella pneumoniae.

MÉTODOS: Uma mulher de 64 anos de idade, com 4 anos de histórico de diabetes mellitus tipo 2, foi admitida no Serviço de Emergência. A paciente apresentava um quadro de dias de febre alta acompanhada de calafrios e um histórico de 5 horas de consciência. Ela recebeu tratamento empírico com antitérmico, após o qual a febre diminuiu.

RESULTADOS: A febre retornou após um intervalo de três horas. Uma tomografia computadorizada do abdome revelou osteomielite vertebral e abcesso bilateral do músculo psoas com formação de gás. A cultura do sangue e o fluido purulento revelaram o crescimento de Klebsiella pneumoniae. A paciente recebeu antibióticos e terapia de drenagem bilateral após o cateter de drenagem ser posicionado na cavidade do abscesso com auxílio de TC. Devido a sérios danos à coluna vertebral e a dor permanente, a paciente foi submetida à fixação vertebral interna minimamente invasiva e recuperou-se com sucesso.

CONCLUSÃo: Um caso de osteomielite vertebral e abscesso do psoas bilateral com a formação de gás causada por Klebsiella pneumoniae em uma paciente diabética. Antibioticoterapia, drenagem e fixação vertebral interna minimamente invasiva foram realizadas, o que permitiu um bom resultado.

PALAVRAS-ChAVE: Osteomielite. Abcesso do psoas. Klebsiella pneumoniae. Procedimentos cirúrgicos minimamente invasivos. Diabetes Mellitus.

\section{REFERENCES}

1. He D, Wu L, Sheng $X$, Xiao Q, Zhu Y, Yu W, et al. Internal fixation with percutaneous kyphoplasty compared with simple percutaneous kyphoplasty for thoracolumbar burst fractures in elderly patients: a prospective randomized controlled trial. Eur Spine J. 2013;22(10):2256-63.

2. Chang CM, Ko WC, Lee HC, Chen YM, Chuang YC. Klebsiella pneumoniae psoas abscess: predominance in diabetic patients and grave prognosis in gas-forming cases. J Microbiol Immunol Infect. 2001;34(3):201-6.

3. Mita N, Narahara H, Okawa M, Hinohara H, Kunimoto F, Haque A, et al. Necrotizing fasciitis following psoas muscle abscess caused by hypermucoviscous Klebsiella pneumoniae. J Infect Chemother 2012;18(4):5658.

4. Gezer A, Erkan S, Saygi Erzik B, Erel CT. Primary psoas muscle abscess diagnosed and treated during pregnancy: case report and literature review. Infect Dis Obstet Gynecol. 2004;12(3-4):147-9.

5. Ricci MA, Rose FB, Meyer KK. Pyogenic psoas abscess: worldwide variations in etiology. World J Surg. 1986;10(5):834-43.
6. Matsumura M, Ito K, Kawamura R, Fujii H, Inoue R, Yamada K. Pneumococcal vertebral osteomyelitis and psoas abscess in a patient with systemic lupus erythematosus disclosing positivity of pneumococcal urinary antigen assay. Intern Med. 2011;50(20):2357-60.

7. McHenry MC, Easley KA, Locker GA. Vertebral osteomyelitis: long-term outcome for 253 patients from 7 Cleveland-area hospitals. Clin Infect Dis. 2002;34(10):1342-50.

8. Menon VK, Kumar KM, Al Ghafri K. One-stage biopsy, debridement, reconstruction, and stabilization of pyogenic vertebral osteomyelitis. Global Spine J. 2014:4(2):93-100.

9. Harrigan RA, Kauffman FH, Love MB. Tuberculous psoas abscess. J Emerg Med. 1995;13(4):493-8.

10. Jang TN, Wang FD, Wang LS, Yu KW, Liu CY. Gram-negative bacillary meningitis in adults: a recent six-year experience. J Formos Med Assoc. 1993;92(6):540-6. 